DOI https://doi.org/10.30525/978-9934-588-91-4-16

\title{
METHODOLOGICAL BASIS OF STUDYING SOVIET SOCIAL POLICY IN THE UKRAINIAN VILLAGE BEFORE THE IMPLEMENTATION OF A NEW ECONOMIC POLICY IN IT
}

\author{
Motuz V. K. \\ Candidate of Historical Sciences, \\ Senior Lecturer at the Department of Archeology \\ and Special Branches of Historical Science \\ Bohdan Khmelnytsky Cherkasy National University \\ Cherkasy, Ukraine
}

There are at least two reasons for the importance of the question. Firstly, the presence in Ukraine of rich experience in the formulation and implementation of social policy, which requires its study and generalization, because it is very important, both for science and for the practice of social development. Secondly, the need to comprehend the experience of implementing social policy in the first years of Soviet power in Ukraine, since it was then that the fundamental foundations were laid and the essential aspects of what can be called the Soviet model of social development were identified.

In this context, it is enough to look at this problem from the standpoint of the methodology of the systems approach and scientific research. In particular, within the framework of the corresponding study, it is assumed not only to disclose the methodological approaches and principles of research used to conduct a comprehensive analysis of such a topic as the Soviet social policy in the Ukrainian countryside before the introduction of the new economic policy, but also to represent the author's approach to the controversial issues within research methodology.

The scientific principles of objectivity, historicism, determinism and consistency served as the methodological basis for the study of the Soviet social policy of the Ukrainian countryside before the introduction of the new economic policy. As you know, the observance of these principles requires consideration of individual phenomena and facts in their development and interrelation, taking into account the entire totality and diversity from the point of view of historical conditioning [3, p. 28].

In accordance with the principles of scientific objectivity in the study of Soviet social policy in relation to the Ukrainian countryside, prior to the introduction of a new economic policy, the entire set of information revealed in the course of the study on the problems of the subject of research should be considered [1, p. 164-165]. 
As for the principle of historicism, it conditioned the study of the social policy of the Soviet state, as an integral part of Soviet policy as a whole. In this case, historical phenomena should be considered in its development, taking into account the previous stages and their subsequent changes, proceeding, if necessary, outside the chronological framework of the study [2, p. 57].

The objective necessity in the application of the principles of determinism and consistency is that they both contribute to the disclosure of conditionality and an objective assessment of the activities of the Soviet state on the development of the social sphere of the Ukrainian village before the introduction of a new economic policy [5, p. 43].

Along with this, the study of the Soviet social policy of the Ukrainian village before the introduction of a new economic policy in it should rely on both the formational and civilizational approaches [3, p. 31]. But considering that modern humanitarian knowledge is integrative, it should also be based on a set of interdisciplinary research methods [4, p. 623].

The study of the Soviet social policy of the Ukrainian village before the introduction of a new economic policy in it requires the author of the scientific study to comply with the requirements of the value approach. This is when a person with his interests and mentality is placed at the center of the historical analysis of Soviet social policy in the Ukrainian village [5, p. 52].

When studying the material on the Soviet social policy of the Ukrainian village before the introduction of the new economic policy, the possibilities of the formational approach to the analysis of phenomena and processes in the socio-cultural life of the village are used, which, allows to determine the socio-political attitudes and features of the social behavior of the peasantry regarding the Soviet social policy [1, p. 171].

This study uses a certain set of general scientific research methods analysis, synthesis, deduction, induction, analogy, statistical method, classification method, as well as special historical methods - frontal survey of sources, actualization method, comparative historical and problemchronological methods [3, p. 46].

General scientific research methods make it possible to single out key events in the process of formation and implementation of the social policy of the Soviet state in the Ukrainian village before the introduction of a new economic policy in it into their definite cause-and-effect series [4, p. 624].

Regarding the method of frontal examination of the sources studied in the course of studying the problem of the Soviet social policy of the Ukrainian countryside before the introduction of the new economic policy, it is used for all their main types [2, p. 58].

The use of the problem-chronological method of research in the study of Soviet social policy regarding the Ukrainian village before the introduction of the new economic policy in it makes it possible to identify the general historical background against which the processes that were studied took place 
[1, p. 174]. Also, its application contributes to the analysis of the main phenomena and processes of the socio-political and sociocultural nature of the life of the Ukrainian village before the introduction of the new economic policy under the influence of the policy of the Soviet state [5, p. 61].

As for the actualization method, it was used to generalize the positive and negative experience of the practice of implementing the Soviet social model in relation to the Ukrainian countryside before the introduction of the new economic policy and to obtain historical lessons for modern social policy [3, p. 49].

In addition, studies of the Soviet social policy of the Ukrainian countryside before the introduction of a new economic policy in it is based on the use of both a sociological approach and political science methods.

The first allows us to identify the dependence of political processes on the development of society as a whole, on its social structure, ideology and political culture [2, p. 60], and the second - institutional and structuralfunctional methods, allow us to consider the role of the main elements of the Soviet political system in the formation and implementation of social policy in general and its sociocultural dimension in particular [4, p. 625].

So, presenting the problem of the Soviet social policy of the Ukrainian village before the introduction of a new economic policy in it through the prism of the methodology of its research, the author of the scientific research came to the conclusion that all of the above methods should be used in combination to provide an integrated approach in the study that allows solving the goals and objectives set in scientific work.

\section{References:}

1. Косміна В. Проблеми методології цивілізаційного аналізу історичного процесу. Запоріжжя: Запорізький національний університет, $2011.310 \mathrm{c}$.

2. Кривчик Г. Основні загальнонаукові методи дослідження в історичних науках. Науково-теоретичний альманах «Грані». 2017. Tом. 20. No 12. C. 55-61. $196 \mathrm{c}$.

3. Санцевич А. Методологія історичного дослідження. К., 1990.

4. Стельмах С. Методологія історії, методологія історичної науки. Енциклопедія історії України: у 10 томах. К.: Наукова думка, 2009. Вип. 6. С. 621-627.

5. Полянський А. Вступ до методології історії. Історія України: проблеми методології та методики. Тернопіль: «Навчальна книга Богдан», 2012. 128 с. 